\title{
Prevalence of Hidradenitis Suppurativa: A Population-Based Study in Olmsted County, Minnesota
}

\author{
Varun Shahi $^{\mathrm{a}}$ Ali Alikhan $^{\mathrm{b}}$ Benjamin G. Vazquez ${ }^{\mathrm{b}}$ Amy L. Weaver ${ }^{\mathrm{c}}$ \\ Mark D. Davis ${ }^{b}$ \\ ${ }^{a}$ Mayo Medical School, Mayo Clinic, ${ }^{b}$ Department of Dermatology, Mayo Clinic, and ${ }^{\mathrm{C} D i v i s i o n}$ of Biomedical \\ Statistics and Informatics, Mayo Clinic, Rochester, Minn., USA
}

\section{Key Words}

Prevalence $\cdot$ Hidradenitis suppurativa $\cdot$ Population-based ·

Follicular occlusion · Acne inversa

\begin{abstract}
Background: Hidradenitis suppurativa (HS) is a follicular occlusion disorder occurring in apocrine-rich regions of the skin. Estimates of the prevalence of this disorder have not been population-based. Objective: We sought to provide population-based information on the prevalence of HS in Olmsted County, Minnesota, as of January 1, 2009. Methods: The Rochester Epidemiology Project, a unique infrastructure that combines and makes accessible all medical records in Olmsted County since the 1960s, was used to collect population-based data on the prevalence of HS. Results: We identified 178 confirmed cases of HS that included 135 females and 43 males, and estimated the total sex-and age-adjusted prevalence in Olmsted County to be 127.8 per 100,000 or $0.13 \%$. The total prevalence was significantly higher among women than men. Conclusion: This study represents the first population-based investigation on the prevalence of HS. In this population-based cohort, HS was less prevalent than suggested by previous reports.

(c) 2014 S. Karger AG, Basel
\end{abstract}

\section{Introduction}

Hidradenitis suppurativa (HS) is a follicular occlusion disorder occurring in apocrine-rich areas that often presents with tender, occasionally draining, papules and nodules with an onset early in puberty, occasionally leading to sinus tract formation $[1,2]$. Associations with other illnesses (e.g. inflammatory bowel disease) have been described [3]. Due to the involvement of many different sites, HS patients may see not only dermatologists, but also general internists, colorectal surgeons, plastic surgeons, gastroenterologists and family physicians [4]. Until recently, population-based epidemiological data for HS had been lacking [2]. Vazquez et al. [2] recently described the incidence of HS in Olmsted County, Minnesota over a four-decade period, providing insight into the rate at which new cases occurred in their population, but did not examine the prevalence of the disorder. Currently, prevalence estimates of HS vary significantly and are primarily restricted to self-reporting $[5,6]$; a recent prevalence study equating HS billing codes to an HS diagnosis did not verify patient notes to ensure validity [7]. To our knowledge, population-based prevalence data for HS have not been reported. The main purpose of this study was to provide population-based data on the prevalence of HS in Olmsted County, Minnesota.

\section{KARGER}

E-Mail karger@karger.com

www.karger.com/drm
(C) 2014 S. Karger AG, Basel

$1018-8665 / 14 / 2292-0154 \$ 39.50 / 0$
Mark D. Davis, MD

Department of Dermatology, Mayo Clinic 200 First St SW

Rochester, MN 55905 (USA)

E-Mail davis.mark2@ mayo.edu 
Table 1. Point prevalence of HS in Olmsted County, Minnesota as of January 1, 2009

\begin{tabular}{|c|c|c|c|c|c|c|c|}
\hline \multirow{2}{*}{$\begin{array}{l}\text { Age as of } \\
\text { January } 1 \text {, } \\
2009 \text {, years }\end{array}$} & \multicolumn{2}{|c|}{ Total } & \multicolumn{2}{|c|}{ Female } & \multicolumn{2}{|c|}{ Male } & \multirow{2}{*}{$\begin{array}{l}\text { Females } \\
\text { vs. males, } \\
\text { p value }\end{array}$} \\
\hline & $\mathrm{n}$ & $\begin{array}{l}\text { prevalence } \\
\text { per } 100,000\end{array}$ & $\mathrm{n}$ & $\begin{array}{l}\text { prevalence } \\
\text { per } 100,000\end{array}$ & $\mathrm{n}$ & $\begin{array}{l}\text { prevalence } \\
\text { per } 100,000\end{array}$ & \\
\hline $0-19$ & 2 & $5.1(0.6-18.4)$ & 2 & $10.4(1.3-37.7)$ & 0 & 0 & 0.14 \\
\hline $20-29$ & 35 & $180.9(126.0-251.5)$ & 31 & $307.7(209.1-436.7)$ & 4 & $43.1(11.7-110.4)$ & $<0.001$ \\
\hline $30-39$ & 39 & $197.9(140.7-270.6)$ & 27 & $276.8(182.4-402.8)$ & 12 & $120.6(62.3-210.6)$ & 0.013 \\
\hline $40-49$ & 35 & $174.3(121.4-242.4)$ & 28 & $276.1(183.5-399.1)$ & 7 & $70.4(28.3-145.1)$ & $<0.001$ \\
\hline $50-59$ & 32 & $163.5(111.8-230.8)$ & 22 & $218.3(136.8-330.4)$ & 10 & $105.3(50.5-193.7)$ & 0.048 \\
\hline $60-69$ & 24 & $201.8(129.3-300.2)$ & 16 & $254.9(145.7-413.9)$ & 8 & $142.5(61.5-280.7)$ & 0.17 \\
\hline $70-79$ & 9 & $124.4(56.9-236.2)$ & 8 & $204.9(88.4-403.7)$ & 1 & $30.1(0.8-167.5)$ & 0.026 \\
\hline $80+$ & 2 & $38.4(4.6-138.7)$ & 1 & $30.2(0.8-168.3)$ & 1 & $52.7(1.3-293.4)$ & 0.66 \\
\hline Total & 178 & $127.8(108.9-146.8)^{\mathrm{a}}$ & 135 & $189.5(157.4-221.7)^{\mathrm{b}}$ & 43 & $65.5(45.6-85.3)^{\mathrm{b}}$ & $<0.001$ \\
\hline
\end{tabular}

Figures in parentheses are $95 \%$ CIs.

a Age- and sex-adjusted to the population structure of the 2010 US white population. ${ }^{\mathrm{b}}$ Age-adjusted to the population structure of the 2010 US white population.

\section{Materials and Methods}

\section{Study Setting}

The resources of the Rochester Epidemiology Project (REP), a unique infrastructure that combines and makes accessible all medical records from Olmsted County, Minnesota, beginning in the 1960s, were utilized to identify the cases [8-10]. The REP is a wellestablished and well-researched epidemiology resource; it is particularly effective because healthcare providers in Olmsted County use a single medical record system that allows an individual's medical information to be accessed from a centralized database [11, 12]. The REP is successful for many reasons. First, the population is relatively isolated (approximately 90-120 min from large metropolitan areas). For this reason virtually all of the healthcare delivered to the community is provided by a small number of healthcare providers. Second, all of these providers (with the exception of approximately 20 dental practices, 6 optometrists and 3 mental health practitioners/psychologists) participate in the REP. For this reason, all conditions that come to medical attention at these providers (including all dermatologic diagnoses) are captured through this research infrastructure. Third, the data come directly from the healthcare providers - not from an insurance group, which would capture only part of the population.

Olmsted County is located in southeastern Minnesota. It has a population of roughly 144,000 people, most of whom identify as white (83\%) according to the 2010 census [13]. Approval from both the Mayo Clinic and the Olmsted Medical Center institutional review boards was obtained prior to commencing the study.

\section{Study Criteria}

Prevalent HS cases were defined as living Olmsted County residents as of January 1, 2009 with a prior diagnosis of HS between January 1, 1968 and December 31, 2008, who had not denied access to their medical records for research purposes. Cases were identified using HS-specific diagnosis codes including Hospital Adaptation of the International Classification of Diseases (HICDA) codes ('hy- dradenitis, NOS', 'hidradenitis, suppurative', 'hydradenitis, suppurative', 'hidradenitis, NOS', 'hydradenitis, NOS' and 'infection, sweat gland'), Berkson codes ('hydrosadenitis', 'inflammation, sweat gland', 'hydradenitis, hydro-adenitis, hidrosadenitis' and 'hidradenitis, hidro-adenitis, hidrosadenitis'), and the International Classification of Disease-9 code ('hidradenitis'). Comprehensive chart review was performed by two abstractors (B.G.V. and A.A.) to determine whether each case met the criteria for HS diagnosis. Though not common, patients for whom a consensus could not be made were excluded from the study. A confirmed HS diagnosis was based on the presence of chronic (defined as being present for greater than 6 months in length from the onset of symptoms), bilateral, typical lesions present along the milk line or in the perianal and/or perineal regions [2]. A third abstractor (V.S.) reviewed the medical records to confirm Olmsted County residency as of January 1, 2009.

\section{Statistical Analysis}

The point prevalence of HS in Olmsted County was calculated assuming that the entire population of Olmsted County for 2009 was at risk. Age- and sex-specific denominator values for 2009 were derived using linear interpolation of the 2000 and 2010 census data for Olmsted County. Statistical tests and 95\% confidence intervals (CIs) were constructed assuming that the number of prevalent HS cases follows a Poisson distribution. The prevalence estimates were age- and sex-adjusted to the population distribution of US whites in the year 2010. Statistical analysis was performed using the SAS version 9.2 software package (SAS Institute, Inc., Cary, N.C., USA).

\section{Results}

Between 1968 and 2008, 1,263 patients who had received a diagnosis of HS were identified using the REP resources. Of these patients, 303 met the criteria for a con- 
Table 2. Estimated prevalence of the present study compared to previous studies

\begin{tabular}{llllll}
\hline Reference & Year & $\begin{array}{l}\text { Study } \\
\text { methodology }\end{array}$ & $\begin{array}{l}\text { Prevalence } \\
\text { estimate, year }\end{array}$ & $\begin{array}{l}\text { Geographic } \\
\text { region }\end{array}$ & $\begin{array}{l}\text { Prevalence } \\
\text { estimate }\end{array}$
\end{tabular}

\begin{tabular}{|c|c|c|c|c|c|c|}
\hline $\begin{array}{l}\text { Present } \\
\text { study }\end{array}$ & 2014 & $\begin{array}{l}\text { Retrospective } \\
\text { analysis of a county }\end{array}$ & 2009 & $\begin{array}{l}\text { Olmsted } \\
\text { County, }\end{array}$ & $0.13 \%$ & $\begin{array}{l}\text { Subjects were residents of the county, } \\
\text { still alive as of January } 1,2009 \text {, and }\end{array}$ \\
\hline
\end{tabular}
population-based Minn., USA met the following criteria between 1968 cohort, all ages and 2008: a HS-specific diagnosis and presence of chronic (defined as being present for $>6$ months from the onset of symptoms), bilateral, typical lesions along the milk line or in the perianal and/ or perineal regions.

\begin{tabular}{lllll}
\hline $\begin{array}{l}\text { Cosmatos } \\
\text { et al. [7] }\end{array}$ & Retrospective & 2007 & USA & $0.05 \%$ \\
& $\begin{array}{l}\text { analysis of an } \\
\text { insurance claims } \\
\text { database, all ages } \\
(\mathrm{n}=7,927)\end{array}$ & & \\
& & & \\
& & &
\end{tabular}

Subjects had a medical insurance claim that met the following criteria in 2007:

1 or more diagnoses with International Classification of Diseases, Ninth Revision, Clinical Modification code 705.83 for HS without a Current Procedural Terminology code for HS; 1 or more Current Procedural Terminology codes of 11450, 11451, 11462, 11463, 11470, or 11471 during 2007 without International Classification of Diseases, Ninth Revision, Clinical Modification code 705.83; or both.

\begin{tabular}{|c|c|c|c|c|c|c|}
\hline $\begin{array}{l}\text { Revuz } \\
\text { et al. [5] }\end{array}$ & 2008 & $\begin{array}{l}\text { Survey mailed to } \\
\text { a random sample } \\
\text { of individuals, age } \\
15 \text { years or older } \\
(\mathrm{n}=6,887)\end{array}$ & 2002 & France & $0.97 \%$ & $\begin{array}{l}\text { Subjects endorsed the following question: } \\
\text { 'During the last } 12 \text { months did you } \\
\text { repeatedly have big nodules or boils located } \\
\text { in the armpits or groin, a disease called } \\
\text { HS?' }\end{array}$ \\
\hline \multirow[t]{2}{*}{$\begin{array}{l}\text { Jemec } \\
\text { et al. [14] }\end{array}$} & 1996 & $\begin{array}{l}\text { Random sample } \\
\text { of individuals } \\
\text { invited for health } \\
\text { examination, age } \\
\text { 15-69 years } \\
(\mathrm{n}=599)\end{array}$ & Not stated & $\begin{array}{l}\text { Copenhagen } \\
\text { County, } \\
\text { Denmark }\end{array}$ & $\begin{array}{l}1 \% \text { (none } \\
\text { with active } \\
\text { disease) }\end{array}$ & $\begin{array}{l}\text { Subjects endorsed the following question: } \\
\text { 'Have you had painful boils in the armpit } \\
\text { or the groin during the last } 12 \text { months?' }\end{array}$ \\
\hline & & $\begin{array}{l}\text { Consecutive } \\
\text { series of patients } \\
\text { attending a } \\
\text { sexually } \\
\text { transmitted disease } \\
\text { clinic }(n=507)\end{array}$ & 1992-1994 & $\begin{array}{l}\text { Copenhagen } \\
\text { County, } \\
\text { Denmark }\end{array}$ & $4.1 \%$ & $\begin{array}{l}\text { Subjects were identified as having presence } \\
\text { of nodules or inflamed lesions compatible } \\
\text { with a diagnosis of HS, or the presence of } \\
\text { non-inflamed nodular lesions and } \\
\text { comedones in the axillae or groin. Subjects } \\
\text { who had 'furuncles' elsewhere were not } \\
\text { counted as cases so as to exclude } \\
\text { staphylococcal infection. }\end{array}$ \\
\hline $\begin{array}{l}\text { Jemec } \\
{[15]}\end{array}$ & 1988 & $\begin{array}{l}\text { Randomly selected } \\
\text { female hospital } \\
\text { staff and patients } \\
\text { referred for } \\
\text { cosmetic excision } \\
\text { of nevi or warts, } \\
\text { age } 17-59 \text { years } \\
(n=100)\end{array}$ & Not stated & Not stated & $4 \%$ & $\begin{array}{l}\text { The diagnosis of HS was based on the } \\
\text { clinical presentation and a history of } \\
\text { recurrent and chronic inflammation, } \\
\text { recurring at the same place in the groin, } \\
\text { under the arms, between the buttocks or } \\
\text { on the breasts, the lesions suppurating } \\
\text { and unresponsive to normal treatment } \\
\text { for boils, such as lancing. }\end{array}$ \\
\hline
\end{tabular}


firmed HS diagnosis. As of January 1, 2009, 20 of the 303 patients were deceased and 105 were no longer residents of Olmsted County, leaving 178 living Olmsted County residents with a diagnosis of HS prior to January 1, 2009. The 178 prevalent cases included 135 females and 43 males, of whom 156 (87.6\%) were white. The mean age as of January 1, 2009 was 45.2 years (standard deviation 15.6; range 16.2-81.4). The point prevalence per 100,000 as of January 1,2009, stratified by age and sex, is summarized in table 1 . The total sex- and age-adjusted prevalence in Olmsted County was 127.8 per 100,000 or $0.13 \%$ (95\% CI 108.9-146.8). The total prevalence was significantly higher among women than among men: 189.5 per 100,000 (95\% CI 157.4-221.7) and 65.5 per 100,000 (95\% CI 45.6-85.3), respectively ( $\mathrm{p}<0.001)$. The highest prevalence was among women aged 20-29 years in 2009 (307.7 per 100,000). Among men, the highest prevalence was between 60 and 69 years (142.5 per 100,000). 60-69 years was also the age range with the highest overall prevalence (201.8 per 100,000$)$. A sharp decline of prevalence was appreciated after 60-69 years for men, while this decline was not seen in women until after 70-79 years. Table 2 compares our reported prevalence against previous studies.

\section{Discussion}

We report a prevalence of $0.13 \%$ in this populationbased study. The prevalence is significantly higher among women, particularly between the ages of 20 and 29 years. Cases had to meet strict criteria which were reconfirmed as part of the chart review.

Some studies have reported prevalence to be at about $1 \%$ [5], while others have reported a prevalence as high as $4 \%$ [14]. Such claims would propose HS to be a more widespread disease; however, it is important to keep in mind that these were not population-based studies and many relied on self-reporting $[5,6]$. A recent study that relied on coding for diagnosis did not examine the patient records to ensure that the cases were likely HS and not some other skin condition occurring in apocrine glandbearing areas [7]. This is important because many of the cases that were reviewed in our study were excluded because they did not meet the criteria described by Alikhan et al. [1]. Upon examining the notes we found that many cases coded as HS were actually dermatitis, epidermal cysts, furuncles or other skin conditions.

Our study has several important limitations that warrant consideration. Though we included patients with a diagnosis made before January 1, 2009, these patients may not have had active symptoms as of January 1, 2009, thus prevalence may be overestimated. Furthermore, due to our strict inclusion criteria, mild or early cases may have been excluded, which could underestimate prevalence. However, it is important to note that many cases of HS are falsely diagnosed as such simply because the symptoms occur in anatomical areas common for HS [2]. Furthermore, detection bias may be likely since women are more likely to access healthcare, which may explain the higher prevalence in women. Additionally, our results may have limited generalizability since we examined one predominantly white county in Southeast Minnesota. Nevertheless, to our understanding, this study represents the first population-based investigation on the prevalence of HS. Finally, the capture of cases is dependent on the patient approaching a healthcare provider and on recognition of the condition of interest. For that reason, the estimates reported in the paper may be an underestimate of the true burden of this condition in the community.

It is important to know the prevalence of HS since it gives us an idea of how many people in our population currently have this chronic illness. No prior population studies on the prevalence of HS have been done, thus this paper adds to the literature of HS. We purport that HS is a rare disease affecting significantly more women than men. We recommend further population-based studies in other parts of the country and world to help further elucidate the epidemiology of this chronic, potentially debilitating disorder.

\section{Acknowledgement}

The study data were obtained from the REP, which is supported by the National Institute on Aging of the National Institutes of Health under award number R01 AG034676. The content of this paper is solely the responsibility of the authors and does not necessarily represent the official views of the National Institutes of Health. Mr. Varun Shahi and Dr. Mark D. Davis had full access to all the data in the study and take responsibility for the integrity of the data and the accuracy of the data analysis.

\section{Disclosure Statement}

The authors state no conflict of interest. 


\section{References}

1 Alikhan A, Lynch PJ, Eisen DB: Hidradenitis suppurativa: a comprehensive review. J Am Acad Dermatol 2009;60:539-561; quiz 562563.

-2 Vazquez BG, Alikhan A, Weaver AL, Wetter DA, Davis MD: Incidence of hidradenitis suppurativa and associated factors: a populationbased study of Olmsted County, Minnesota. J Invest Dermatol 2013;133:97-103.

-3 van der Zee HH, van der Woude CJ, Florencia EF, Prens EP: Hidradenitis suppurativa and inflammatory bowel disease: are they associated? Results of a pilot study. Br J Dermatol 2010;162:195-197.

4 Brown TJ, Rosen T, Orengo IF: Hidradenitis suppurativa. South Med J 1998;91:1107-1114.

$\checkmark 5$ Revuz JE, Canoui-Poitrine F, Wolkenstein P, Viallette C, Gabison G, Pouget F, Poli F, Faye O, Roujeau JC, Bonnelye G, Grob JJ, BastujiGarin S: Prevalence and factors associated with hidradenitis suppurativa: results from two case-control studies. J Am Acad Dermatol 2008;59:596-601.
6 Esmann S, Dufour DN, Jemec GB: Questionnaire-based diagnosis of hidradenitis suppurativa: specificity, sensitivity and positive predictive value of specific diagnostic questions. Br J Dermatol 2010;163:102-106.

7 Cosmatos I, Matcho A, Weinstein R, Montgomery MO, Stang P: Analysis of patient claims data to determine the prevalence of hidradenitis suppurativa in the United States. J Am Acad Dermatol 2013;68:412-419.

$\checkmark 8$ Melton LJ 3rd: History of the Rochester Epidemiology Project. Mayo Clin Proc 1996;71: 266-274.

-9 Rocca WA, Yawn BP, St Sauver JL, Grossardt BR, Melton LJ: History of the Rochester Epidemiology Project: half a century of medical records linkage in a US population. Mayo Clin Proc 2012;87:1202-1213.

10 St Sauver JL, Grossardt BR, Yawn BP, Melton LJ 3rd, Pankratz JJ, Brue SM, Rocca WA: Data resource profile: the Rochester Epidemiology Project (REP) medical records-linkage system. Int J Epidemiol 2012;41:1614-1624.
1 St Sauver JL, Grossardt BR, Leibson CL, Yawn BP, Melton LJ 3rd, Rocca WA: Generalizability of epidemiological findings and public health decisions: an illustration from the Rochester Epidemiology Project. Mayo Clin Proc 2012;87:151-160.

12 St Sauver JL, Grossardt BR, Yawn BP, Melton LJ 3rd, Rocca WA: Use of a medical records linkage system to enumerate a dynamic population over time: the Rochester Epidemiology Project. Am J Epidemiol 2011;173:10591068.

13 Census BUS: Summary file - Minnesota [machine-readable data files]. Prepared by the 2010 Census Demographic Profile 2011.

14 Jemec GB, Heidenheim M, Nielsen NH: The prevalence of hidradenitis suppurativa and its potential precursor lesions. J Am Acad Dermatol 1996;35:191-194.

15 Jemec GB: The symptomatology of hidradenitis suppurativa in women. Br J Dermatol 1988;119:345-350. 